\title{
Conf $-9504119--2$
}

DOE/METC/C-95/7188

Performance Analysis of Co-Firing Waste Materials in an Advanced Pressurized Fluidized-Bed Combustor

Authors:

Heather M. McDaniel (DOE/METC)

Donald L. Bonk (DOE/METC)

Michael R. DeLallo, Jr. (Gilbert/Commonwealth, Inc.)

Roman Zaharchuk (Gilbert/Commonwealth, Inc.)

Conference Title:

Solid Waste Management Thermal Treatment and Waste-to-Energy

Technologies Conference

Conference Location:

Washington, D.C.

Conference Dates:

April 18 - 21, 1995

Conference Sponsor:

Air and Waste Management

American Society of Mechanical Engineers

Environment Canada

Integrated Waste Services Association

U.S. Environmental Protection Agency

National Renewable Energy Laboratory

Solid Waste Association of North America

U.S. Department of Energy 


\section{DISCLAIMER}

Portions of this document may be illegible in electronic image products. Images are produced from the best available original document. 


\title{
Performance Analysis of Co-Firing Waste Materials in an Advanced Pressurized Fluidized-Bed Combustor
}

\author{
Donald L. Bonk \\ Heather M. McDaniel \\ U.S. Department of Energy \\ Morgantown Energy Technology Center \\ Morgantown, West Virginia
}

\author{
Michael R. DeLallo, Jr. \\ Roman Zaharchuk \\ Gilbert/Commonwealth, Inc. \\ Reading, Pennsylvania
}

\begin{abstract}
The co-firing of waste materials with coal in utility scale power plants has emerged as an effective approach to produce energy and manage municipal wastes. Leading this approach is the atmospheric fluidized-bed combustor (AFBC). It has demonstrated its commercial acceptance in the utility market as a reliable source of power by burning a variety of waste and alternative fuels. The fluidized-bed, with its stability of combustion, reduces the amount of thermochemical transients and provides for easier process control. The application of pressurized fluidized-bed combustor (PFBC) technology, although relatively new, can provide significant enhancements to the efficient production of electricity while maintaining the waste management benefits of AFBC.

A study was undertaken to investigate the technical and economical feasibility of co-firing a PFBC with coal and municipal and industrial wastes. Focus was placed on the production of electricity and the efficient disposal of wastes for application in central power station and distributed locations. Issues concerning waste material preparation and feed, PFBC operation, plant emissions, and regulations are addressed. The results and conclusions developed are generally applicable to current and advanced PFBC design concepts.

Wastes considered for co-firing include municipal solid waste (MSW), sewage sludge, and industrial de-inking sludge. Conceptual designs of two power plants rated at $250 \mathrm{MWe}$ and $150 \mathrm{MWe}$ were developed. Heat and material balances were completed for each plant along with environmental issues.

With the PFBC's operation at high temperature and pressure, efforts were centered on defining feeding systems capable of operating at these conditions. Since PFBCs have not been tested co-firing wastes, other critical performance factors were addressed and recommendations were provided for resolving potential technical issues. Air emissions and solid wastes were characterized to assess the environmental performance comparing them to state and Federal regulations. This paper describes the results of this investigation, presents conclusions on the key issues, and provides recommendations for further evaluation.
\end{abstract}

\section{INTRODUCTION}

A study has been undertaken to investigate the technical and economical feasibility of co-firing a pressurized fluidized-bed combustor $(\mathrm{PFBC})$ with coal and municipal or industrial wastes. Focus was placed on the production of electricity and the efficient disposal of wastes for application in a central power station and distributed locations. Wastes considered for co-firing include municipal solid 
waste (MSW), municipal sewage sludge, and industrial de-inking sludge. Issues concerning waste material preparation and feed, PFBC operation, plant emissions, and regulations are addressed. This paper describes the results of the performance evaluation completed as part of this study, and provides recommendations for further evaluation.

\section{BACKGROUND INFORMATION}

The Environmental Protection Agency's (EPA) 1990 estimates place the amount of MSW generated in the United States at over 195 million tons per year, up approximately 44 million tons since $1980^{(1)}$. EPA estimates that 4.3 pounds of MSW are generated per person per day. Together with industrial process waste and municipal sewage sludge, the resultant burden on our capacity to dispose of these wastes, in a cost-effective and environmentally acceptable manner, is an enormous management problem.

One method of waste management is through combustion or incineration with energy recovery. This alternative has been plagued with a legacy of inefficient, dirty, and poorly operated incinerators, resulting in environmental problems leaving communities searching for solutions. However, advanced power systems that can meet new stringent environmental regulations have been developed and operated successfully. Additionally, electric utilities and non-utility generators have shown significant interest in waste management through waste-to-energy facilities.

Co-firing waste with coal in a utility scale boiler has emerged as an effective approach to produce energy from wastes. Fluidized-bed combustors are becoming a primary method of burning wastes. The fluidized-bed, with its stability of combustion and temperature, provides enhanced energy recovery and environmental control while achieving cost-effective waste management.

\section{Waste Material Characteristics}

The characteristics and analyses of the three waste fuels under consideration were obtained from facilities that presently co-fire these materials. The wastes are municipal solid waste, municipal sewage sludge, and industrial de-inking sludge.

Municipal Solid Waste. Waste classified as MSW is extremely variable in composition both on a seasonal and location basis. To produce a fuel that can be fed to a PFBC, it must be processed to remove metal, glass, and other non-combustibles to produce what is called refuse-derived fuel (RDF). Methods currently used process about 50 percent of MSW to RDF. A typical 3-inch shredded material is prepared by shredding, magnetic separation, and air classification. It can be burned as is, pelletized, or slurried. A representative RDF proximate and ultimate analysis is shown in Table 1.

Municipal Sewage Sludge. The incineration of sewage sludge has a long history in the United States. Initially, multiple hearth units were used; now the majority of new installations are FBCs.

Treatment plant sludges generally are less than 7 percent total solids (t.s.). Combinations of processes such as chemical addition, flocculation, thermal conditioning, gravity thickening, and centrifugation are used to thicken sludge prior to burning. Feed sludges range from 20 percent to 40 percent t.s., but 25 percent t.s. is a reasonable average.

Sludge analyses vary from plant to plant and from season to season in the same plant. The fibrous nature of sewage sludge greatly affects the fluidity. A 7 percent $t$.s. sludge has the consistency of wet cement. At 25 percent t.s., sludge can be conveyed "dry" on a conveyor belt. Table 2 is an ultimate analysis of a sludge that has 13.85 percent t.s. On a dry basis, the Higher Heating Value (HHV) of sludge can be as high as $6,500 \mathrm{Btu} / \mathrm{lb}$.

De-Inking Sludge. The amount of de-inking sludge produced is increasing as the use of recycled paper is gaining popularity. In the manufacture of newsprint, the repulping generates a large quantity of high-ash sludge, which previously was disposed of in lagoons. Now, incineration in fluidized-bed combustors is preferred since overall energy costs can be reduced and environmental requirements can be satisfied. The pulping process in a typical size facility produces $250 \mathrm{dry}$ tons of de-inking sludge per day from a feed of 1,600 dry tons per day of old newsprint.

The sludge is concentrated from a 2 percent t.s. stream to 7 percent and is further de-watered to 
45 percent t.s. using screw presses. The character of 45 percent sludge is such that storage bins are not used. The sludge is processed and conveyed directly to the boiler on conveyor belts. Table 3 shows a representative sludge analysis.

\section{Design and Operation Issues}

Although there is considerable data on the operation of PFBCs when feeding coal both dry and as a slurry, wastes have not been co-fired with coal. There is, however, considerable information on co-firing wastes in atmospheric fluidized-bed combustors (AFBC) that is relevant. Except for pressure, AFBCs have similar operational requirements. Feeding the wastes into the combustors has been the most common problem. This prompted an investigation as to what equipment is available to feed RDF and sludges into a PFBC.

The flow and handling characteristics of the waste materials considered in this study are affected by quality, moisture content, particle size, and extraneous contaminants. Feeding these materials into pressure vessels differs greatly from feeding into atmospheric processes due to pressure influences on the tension and compression strength of the feed material. Recently, there has been activity in developing pressurized feeders for biomass waste materials and both dry and slurry feeders have been tested. Dry feed systems include double lockhoppers, rotary valve feeders, piston feeders, screw feeders, and pneumatic systems. Slurry feeders include progressive cavity pumps, piston pumps, and rotary feeders. However, these options have not had substantial operating experience at PFBC conditions, but it is assumed that eventually a reliable system will be available. The slurry feeders have had the advantage based on experience feeding coal slurries, but there is a penalty effect on performance especially when feeding high-moisture slurries. Table 4 presents some of the dry feeders evaluated.

\section{PROJECT DESCRIPTION}

Design and performance analyses were developed for PFBC advanced-generation plant configurations with nominal ratings of $110 \mathrm{MWe}$ and $250 \mathrm{MWe}$. Performance considerations were given to fuel handling, emission control, and residual solids handling. Thermal performance for all cases was calculated by using an Aspen/SP ${ }^{\mathrm{TM}}$ modular computer program. The program modeled the $\mathrm{PFBC}$, gas turbine, heat recovery and steam generator, and the steam turbine cycle in a single, integrated calculation process. Plant material and energy balances were developed along with the net plant power, thermal efficiency, and net heat rate. Comparisons were made to firing with and without waste materials to define the effects on plant performance from waste co-firing.

\section{RESULTS}

The design and performance analyses for the PFBC power plant co-fired with RDF and/or sludge waste followed two application scenarios. The first assumed a utility base load application with electrical production in the 100 to $120 \mathrm{MWe}$ range, and the second assumed a capacity of 240 to $250 \mathrm{MWe}$. Application specifics were then based on these scenarios including the definition of site and ambient conditions; fuel, waste, and sorbent feedstock; and method of fuel/waste handling. The PFBC 1.5-Generation plant configuration as presented in Figure 1 is the basis for this study and is used to establish the baseline performance. The study utilized defined plant boundary conditions including ISO ambient conditions, Pittsburgh 8 coal, Plum Run dolomite, and waste feedstock for each PFBC application analysis.

The ratio of coal-to-waste fuel was established on the following criteria: (1) an 80:20 coal-towaste ratio on an as-received weight basis was used to define the maximum amount of co-fired waste products, and (2) co-fired amounts for municipal sewage sludge were based on the volume produced from a typical population center of 250,000 , employing a typical sludge treatment process.

Co-fired amounts for municipal sewage sludge were based on the volume produced from a typical population center employing a representative sludge treatment process. Population data was obtained from the 1992 Statistical Abstracts of the United States, 112th edition. The abstract provides 
population data as defined for Metropolitan Statistical Areas (MSAs) and Consolidated Metropolitan Statistical Areas (CMSAs) for 1990. From this information, the median population of the MSAs for 1990 was determined. A population base of 250,000 was then selected for determining the amount of waste feedstock.

The volume of municipal sewage sludge produced per capita at a treatment facility is dependent upon the influent wastewater characteristics, the process efficiency for reducing pollutants, and the type of sludge treatment process. The most commonly used Primary Sedimentation and Activated Sludge, digested treatment processes, have been selected to represent the treatment process for supply of sewage sludge to the PFBC plant. For the primary sedimentation and activated sludge treatment process the typical quantity of sludge produced per capita is $0.14 \mathrm{dry} \mathrm{lb} /$ day with a moisture content of 60 to 94 percent ${ }^{(2)}$.

An overview of the relationships between the waste feedstock and per capita production rates are presented in Table 5.

\section{Design Review}

Major subsystems specifically influenced by the waste material feedstock are fuel handling, emission control, and residual solids handling. Of particular concern to this study is the impact on system performance from variations in the fuel/waste handling process.

Fuel Handling Options. The analyses investigated slurry processing of the coal and sorbent in either: (1) separate combustor feed of the coal/sorbent and waste streams, or (2) combined coal/sorbent and waste fired in a slurry media. As an alternative approach to slurry feeding, a sensitivity study of dry feeding of coal, sorbent, and the co-fired RDF was completed at the $250 \mathrm{MWe}$ level. The analysis compared overall plant efficiency and cost-of-electricity to determine if an advantage exists in dry versus slurry feed. In the slurry feed approach, the coal and sorbent are transported via a water media at 75 percent total solids.

Waste Material Handling. For the $250 \mathrm{MWe}$ system, RDF is fed to the PFBC as a slurry or pneumatically to determine which method proved higher system efficiency and lower economics of operation. For the slurry feed analysis, RDF is combined with coal and sorbent and slurried with water to 75 percent t.s. The slurry is then pumped into the PFBC. The inherent moisture of RDF was not considered to be used as part of the slurry water content.

In the case of dry feed, the RDF is fed to the PFBC via a screw conveyor. In this case, coal and sorbent are pneumatically conveyed to the PFBC. Separate feed systems allow different fuel injection points in the combustor. In this manner, the relatively light RDF material can be fed to the PFBC at a point to assure complete combustion.

For municipal sludge, it was assumed to be dewatered to 24 percent t.s. and fed in a separate flow stream to the combustor. A value of 24 percent t.s. corresponds to the industry achievable de-watering capability with conventional belt filter or screw press.

Based on a population value of 250,000 supplying the municipal sludge, a feed rate of $35,000 \mathrm{lb} /$ day was assumed in both the $250 \mathrm{MWe}$ and $110 \mathrm{MWe}$ performance analysis. At this input rate, the coal-to-waste feed ratio, on an as-received weight basis, is 95:5 and 91:9, respectively.

An additional case analysis examined the potential use of as-received municipal sludge at 6 percent t.s. as the slurry media for the PFBC fuel and sorbent. The limiting factor for this analysis was the requirement to maintain a 75 percent t.s. in the fuel and sorbent feed.

For the analysis of de-inking sludge, it was assumed that a 40 percent t.s. is fed to the PFBC via piston feeder. At this percent solids, de-inking sludge cannot be pumped in a conventional fluid pump. A sludge total solids value of 40 percent was chosen to represent the industry standard in recycled newsprint facility operation. Separate feed systems for the coal/sorbent slurry and de-inking sludge allow for different fuel injection points. In this manner, the relatively light sludge material can be fed to the PFBC at a point that will inhibit rapid ascension of the sludge material assuring complete combustion. The coal-to-waste firing ratio of 80:20 was assumed, on a weight basis, and is based on as-received coal and "bone-dry" de-inking sludge. 


\section{Performance Analysis Assumptions}

The design and performance analyses for a PFBC power plant co-firing RDF and/or sludge waste followed similar application scenarios. Operational conditions were established assuming a utility base load application located in the United States' mid-Atlantic region.

The $250 \mathrm{MWe}$ application includes the use of a Westinghouse 501D5 gas turbine with an $1800 / 1000 / 1000$ steam turbine bottoming cycle. The performance for the $110 \mathrm{MWe}$ is based on using a Westinghouse W251B12 gas turbine with a 1450/1000/ 1000 steam turbine bottoming cycle.

The PFBC combustor design parameters were assumed to follow the design assumptions defined in Gilbert/ Commonwealth Report No. $2985^{(3)}$. The PFBC is a circulating-bed with an operating temperature in the $1600^{\circ} \mathrm{F}$ range. A 99.3 percent carbon conversion efficiency was assumed for performance modeling along with a 93.3 sulfur removal.

The performance analysis for the various PFBC power plants co-fired with waste feedstocks were developed according to the application and waste material used.

The case profiles used to define the performance assumptions are as follows:

\section{MWe Application}

250 MWe with Pittsburgh 8 coal and municipal solid waste as RDF in a combined slurry feed at the $80: 20$ coal-to-waste ratio.

$250 \mathrm{MWe}$ Pittsburgh 8 coal and municipal solid waste as RDF as-received in separate dry feeds at the 80:20 coal-to-waste ratio.

$250 \mathrm{MWe}$ Pittsburgh 8 coal and municipal sewage sludge de-watered to 24 percent t.s. with separate feed at a waste feed volume based on a 250,000 population.

$250 \mathrm{MWe}$ Pittsburgh $8 \mathrm{coal}$ and de-inking sludge de-watered to 40 percent t.s. with separate feed at the $80: 20$ coal-to-waste ratio.

\section{MWe Application}

110 MWe with Pittsburgh 8 coal and municipal solid waste as RDF in a combined slurry feed at the 80:20 coal-to-waste ratio.

110 MWe with Pittsburgh 8 coal and municipal sewage sludge de-watered to 24 percent t.s. with separate feed at a waste feed volume based on a 250,000 population.

$110 \mathrm{MWe}$ Pittsburgh $8 \mathrm{coal}$ at 6 percent t.s. municipal sewage sludge to provide a combined slurry feed (coal, sorbent, and waste) at 75 percent t.s. with the slurry media supplied by the waste stream.

$110 \mathrm{MWe}$ Pittsburgh 8 coal and de-inking sludge de-watered to 40 percent total solids with separate feed at the 80:20 coal-to-waste ratio.

\section{Performance Analysis Results}

To further enhance the results of this study, performance comparisons were developed for the 1.5-Generation PFBC with and without co-firing of wastes. The PFBC plant, as presented in Reference 3 , is the basis for this study and was used to establish nominal performance without co-firing wastes.

250 MWe Results. The performance for the $250 \mathrm{MWe}$ PFBC plant without co-firing is shown in Table 6. Also shown are performance values for the same facility co-firing RDF as a slurry and in a dry form, co-firing municipal sewage sludge, and co-firing industrial de-inking sludge.

As indicated, an overall conversion efficiency of 41.38 percent was defined for the facility without co-firing of waste materials. With waste co-firing, conversion efficiencies decreased in the range of 1.0 percent to 2.7 percent depending on the waste co-fired and method of fuel handling. The lowest efficiency is attributable to the highest waste co-firing (industrial de-inking sludge), on a weight basis; thus a lower coal feed rate of approximately 13.6 percent.

In the comparison of alternative fuel and waste handling techniques, the pneumatic feed of coal, sorbent, and RDF had a slightly higher overall conversion efficiency of 40.98 percent compared to 40.39 percent for the slurried case. However, it was determined in follow-up work that the cost-ofelectricity was also higher as a result of the required equipment capital cost for pneumatic feed. 
110 MWe Results. The performance for the $110 \mathrm{MWe}$ PFBC plant without co-firing is shown in Table 7. Performance values for the same facility co-firing RDF as a slurry, co-firing municipal sewage sludge, and co-firing industrial de-inking sludge are also presented for comparison.

As indicated, the overall conversion efficiency of 40.22 percent was defined for the facility without co-firing waste materials. With the additional waste co-firing, conversion efficiencies decreased in the range of 1.3 percent to 2.6 percent depending on the waste co-fired and method of fuel handling. As in the previous analysis, the lowest efficiency is attributable to the co-firing of industrial de-inking sludge.

The RDF co-fired analysis is based on a combined slurry feed system. As indicated, the overall conversion efficiency for the case of co-firing RDF was determined to be 39.29 percent, which represents a 2.3 percent decrease in thermal efficiency from the base case without co-firing. Alternatives in co-firing municipal sewage sludge were investigated at the $110 \mathrm{MWe}$ level. In the first analysis, the coal was co-fired with municipal sewage sludge de-watered to 24 percent t.s. using a separate feed approach. A second analysis assumed a 6 percent t.s. municipal sewage sludge for use in providing a slurry media to transport the combined sludge, coal, and sorbent mixture at 75 percent t.s. This analysis was performed at the $110 \mathrm{MW}$ nominal plant size to investigate the benefits of using the existing as-received municipal sludge as the transport media for the complete fuel, sorbent, and waste feedstock.

As indicated in Table 7, there is no significant performance difference in the combined slurry approach over separate feed. However, a follow-up economic analysis indicated a savings in capital cost and lower cost-of-electricity with this approach. However, by combining the fuel, sorbent, and waste fuel streams, process control and combustor stability may be affected. Further data and analysis of the PFBC combustion parameters is required before accepting the benefits of the combined fuel feed approach.

\section{ENVIRONMENTAL ISSUES}

The Babcock and Wilcox Company $(\mathrm{B} \& W)$ provided assistance in the identification and definition of critical environmental performance parameters of co-firing a pressurized fluidized-bed combustion (PFBC) system with coal and refuse-derived fuel (RDF) and/or sewage sludges. The following presents an overview of environmental performance.

- $\underline{\text { Air }}$

B\&W assumes that the removal of fine particles ( $>10$ microns) by the cross-flow filter will be sufficient to protect the gas turbine and should easily meet regulatory requirements for PM10 emissions.

At the sorbent rates expected to be used in the PFBC system, 90-95 percent $\mathrm{SO}_{2}$ capture is expected. Based on the excess air levels expected in PFBC systems, it is not expected that reducedsulfur compounds will be present in the gas at measurable levels. Based on Pittsburgh 8 coal with 3 percent sulfur, the outlet $\mathrm{SO}_{2}$ concentration would be in the range of $70-140 \mathrm{ppm}$ at 100 percent excess air (for 90-95 percent sulfur capture). NOx will be generated in the pressurized circulating fluidized-bed (PCFB) and in the topping combustor. Therefore, NOx may be higher than in an atmospheric CFB due to higher excess air operation.

Heavy metals (lead, beryllium, cadmium and mercury) will not be removed from this system until after the heat recovery steam generator (HRSG) based on temperature considerations. Therefore, their concentration in the stack gas would likely be higher than for an atmospheric CFB with a baghouse, which provides an opportunity for metals to condense onto particulates. Mercury is a highly volatile metal and may leave the system as a gas. Lead concentrations in the RDF and sewage sludge ash can be an order of magnitude higher than in coal ash. However, it would be expected that the majority of lead would be collected with the ash in the cross-flow filter.

In testing RDF with coal co-firing, B\&W has found that chlorine and fluorine partitioned mainly to the baghouse ash, where the baghouse operated at approximately $300^{\circ} \mathrm{F}$. In the proposed cycle, 
the flue gases pass through this temperature window in the HRSG, which could, depending on the inlet chlorine and fluorine concentration, lead to increased corrosion in the HRSG with co-firing. However, if the chlorine in the RDF feed is actually $<0.01$ percent, the addition of RDF would not result in additional corrosion over firing with coal alone.

Based on the residence time in the system and the high temperature of the topping combustor, B\&W's review indicated a high destruction and removal efficiency (i.e. 99.99 percent) for the organics. Based on B\&W's pilot scale atmospheric bubbling bed testing with $\mathrm{RDF} /$ coal mixtures, they found that when the RDF feed was about 10 percent of the heat input, dioxin and furan emissions were low. Based on the low RDF feed assumed for this study, about 7 percent of the heat input, it is expected that dioxin and furan emissions would not be a problem at these firing rates, especially considering that the gases pass through a $2000^{\circ} \mathrm{F}$ temperature zone in the topping combustor. Atmospheric CFB testing of de-inking sludges also resulted in dioxin/furan emissions that were below both Canadian and United States' environmental regulatory requirements. ${ }^{(4)}$

\section{- Solid Waste (Ash)}

Based on B\&W's pilot scale test experience with coal/RDF mixtures, measurements were made on all but 6 of 40 contaminants (Chlordane, 2-4-Dinitrotoluene, heptachor, Hexachloro- butadience, pyridine, and vinyl chloride). Leachates from bed ash and baghouse ash were tested. Detectable amounts were measured for about 5 of the 44 contaminants measured (arsenic, barium, chromium, lead and mercury). However, none of the contaminants listed were present in amounts that exceeded regulatory limits. The toxicity characteristic leaching procedure contaminants in ash produced from firing an ACFB with De-Inking sludge and coal were also below regulatory levels. ${ }^{(4)}$

\section{CONCLUSIONS}

This study's objective was to investigate co-firing a pressurized fluidized-bed combustor with coal and refuse-derived fuel and/or sludges for the production of electricity and the efficient disposal of waste. Performance evaluation of the PFBC power plant co-fired with RDF and/or sludges showed only slightly lower overall thermal efficiency than similar sized plants without waste co-firing. Major contributors to the slightly lower performance include the waste material preparation and feed systems, and the additional water to support slurry feed of both the coal/sorbent and waste feedstock.

The results also indicate that there are no technology barriers to the co-firing of waste materials with coal in a PFBC power plant. The potential to produce cost-competitive electrical power and support environmentally-acceptable waste disposal exists with this approach. However, as part of technology development, there remain several design and operational areas requiring data and verification before this concept can realize commercial acceptance.

Throughout the analysis, key issues concerning waste material preparation and feed, PFBC operation, plant emissions, and regulations were identified and addressed to the limits of available data. It is important to note that presently there are no known PFBC facilities co-firing coal and waste materials. Available information and performance data is limited to utility and municipalowned facilities co-firing waste in AFBCs and private and Government-funded research and development programs in PFBCs. Correlation of this data is difficult due primarily to the differences in operational parameters, combustion kinetics, and particulate removal temperature profiles. However, data on air/fuel distribution, primary emissions, and in-bed gas residence lend confidence to the use of existing AFBC operational information.

In summary, the key issues for co-firing are feeding waste materials against system pressures (solids handling), materials concerns due to the addition of potentially corrosive constituents, and environmental impact of solid wastes and gaseous emissions. In order to address these issues, pilot scale testing co-firing waste materials should be performed and the results used to predict commercial-scale performance. The testing should be performed in a facility of adequate size so that commercially representative fuel feed sizes and gas residence times can be evaluated. 


\section{ACKNOWLEDGEMENTS}

Acknowledgement is made of substantial assistance from Mark Perna and Daniel Rowley of Babcock \& Wilcox Company. Inquiries related to this report should be addressed to the Product Manager, Pressurized Fluidized-Bed Technology, U.S. Department of Energy at the Morgantown Energy Technology Center.

\section{REFERENCES}

1. Franklin, W.E. and Franklin, M.A. "Putting the Crusade into Perspective." EPA Journal, Volume 18, No. 3 July/August 1992.

2. Process Design Manual Municipal Sludge Landfills, U.S. EPA, EPA-625/1-78-010 SW-705. October, 1978.

3. Gilbert/Commonwealth Report No. 2985, Conceptual Design and Optimization of a 1-1/2 Generation PFBC Plant, Draft Report, September 1993.

4. Municipal Waste-to-Energy Technology Assessment, prepared by Battelle Memorial Institute for Electric Power Research Institute, EPRI TR-100058, Final Report, January, 1992. 
Table 1. Representative RDF analysis.

\begin{tabular}{lclc}
\hline \hline \multicolumn{2}{c}{$\begin{array}{c}\text { Proximate Analysis } \\
\text { As Received }\end{array}$} & \multicolumn{2}{c}{$\begin{array}{c}\text { Ultimate Analysis } \\
\text { As Received }\end{array}$} \\
Moisture & $30.73 \%$ & Moisture & $30.73 \%$ \\
Ash & 11.59 & Ash & 11.59 \\
Volatile & 48.93 & Sulfur & 0.32 \\
Fixed C & 8.75 & Nitrogen & 0.61 \\
& $100.00 \%$ & Carbon & 28.30 \\
& & Hydrogen & 4.20 \\
Btu/lb, HHV & 4,801 & Oxygen & 24.25 \\
& & Total & $100.00 \%$ \\
\hline \hline
\end{tabular}

Table 2. Municipal sewage sludge ultimate analysis.

\begin{tabular}{lc}
\hline \hline Carbon & $3.08 \%$ \\
Hydrogen & 0.46 \\
Nitrogen & 0.37 \\
Sulfur & 0.07 \\
Ash & 6.80 \\
Oxygen & 3.07 \\
Moisture & 86.15 \\
\multicolumn{1}{c}{ Total } & $100.00 \%$ \\
Btu/lb, HHV & 464 \\
\hline \hline
\end{tabular}

Table 3. De-Inking sludge analysis.

\begin{tabular}{|c|c|c|c|}
\hline \multicolumn{2}{|c|}{$\underline{\text { Proximate }}$} & \multicolumn{2}{|c|}{$\underline{\text { Ultimate }}$} \\
\hline Moisture & $55.00 \%$ & Moisture & $55.00 \%$ \\
\hline Ash & 9.76 & Ash & 9.76 \\
\hline Volatile & 28.74 & Sulfur & 0.11 \\
\hline \multirow[t]{3}{*}{ Fixed C } & 6.50 & Nitrogen & 0.35 \\
\hline & $100.00 \%$ & Carbon & 19.58 \\
\hline & & Hydrogen & 2.40 \\
\hline \multirow[t]{2}{*}{ Btu/lb, HHV } & 3,562 & Oxygen & 12.80 \\
\hline & & Total & $100.00 \%$ \\
\hline
\end{tabular}


Table 4. Summary of dry feed systems for high pressure.

\begin{tabular}{|c|c|c|c|c|}
\hline Feeder Type & $\begin{array}{c}\text { PSI } \\
\text { Pressure } \\
\text { (Max) }\end{array}$ & $\begin{array}{c}\mathrm{m} 3 / \mathrm{h} \\
\text { Capacity } \\
\text { (Nominal) }\end{array}$ & $\begin{array}{l}\text { Suitable } \\
\text { For }\end{array}$ & Remarks \\
\hline $\begin{array}{l}\text { Lockhopper } \\
\text { Gravity Feed }\end{array}$ & 500 & 40 & All Wastes & $\begin{array}{l}\text { Unless double LH are } \\
\text { used, compression gas } \\
\text { use could be excessive. }\end{array}$ \\
\hline $\begin{array}{l}\text { Lockhopper } \\
\text { Screw Feed }\end{array}$ & 360 & 14 & All Wastes & $\begin{array}{l}\text { A larger capacity unit } \\
\text { has not been designed. }\end{array}$ \\
\hline Rotary Valve & 175 to 350 & 200 to 280 & All Wastes & $\begin{array}{l}\text { Size should be }<5 \mathrm{~cm} \text {. } \\
\text { Other vendors offer }<200 \\
\text { psi max. feeeders. }\end{array}$ \\
\hline Piston Feeders & 333 to 2175 & 50 to 115 & $\begin{array}{l}\text { All Dry } \\
\text { Wastes }\end{array}$ & $\begin{array}{l}\text { Feeders are more } \\
\text { suitable for dry fuels. } \\
\text { Sludges would have to } \\
\text { be tested. }\end{array}$ \\
\hline Screw Feeders & 250 to 1450 & 20 to 45 & All Wastes & $\begin{array}{l}\text { Expensive. Fibrous and } \\
\text { abrasive materials are a } \\
\text { problem. }\end{array}$ \\
\hline
\end{tabular}

Table 5. Relationship of waste production to population.

\begin{tabular}{ll}
\hline Waste Description & $\begin{array}{l}\text { lb/person } \\
\text { per day }\end{array}$ \\
Municipal Sewage Sludge & 0.14 \\
Tire-Derived Fuel & 0.0055 \\
\hline
\end{tabular}


Table 6. $250 \mathrm{MW}$ PFBC plant performance comparison.

\begin{tabular}{|c|c|c|c|c|c|}
\hline & $\begin{array}{c}\text { W/O Waste } \\
\text { Co-firing }\end{array}$ & $\underline{\mathrm{RDF}}$ & $\begin{array}{c}(\mathrm{DRY}) \\
\underline{\mathrm{RDF}}\end{array}$ & $\begin{array}{l}\text { Municipal } \\
\text { Sludge }\end{array}$ & $\begin{array}{c}\text { De-Inking } \\
\text { Sludge }\end{array}$ \\
\hline \multicolumn{6}{|l|}{ ENERGY INPUT } \\
\hline Coal Feed, lb/hr & 128,861 & 118,313 & 117,691 & 128,885 & 111,329 \\
\hline Coal HHV, Btu/lb & 12,450 & 12,450 & 12,450 & 12,450 & 12,450 \\
\hline Natural Gas, lb/hr & 19,257 & 19,635 & 19,251 & 19,553 & 19,710 \\
\hline Natural Gas HHV, Btu/lb & 21,799 & 21,799 & 21,799 & 21,799 & 21,799 \\
\hline Waste Feed, $\mathrm{lb} / \mathrm{hr}$ & $\cdot$ & 29,578 & 28,367 & 6,076 & 69,581 \\
\hline Waste HHV, Btu/lb & & 4,103 & 4,103 & 804 & 3,166 \\
\hline Plant Energy Input, MW & 595.181 & 592.713 & 588.256 & 596.628 & 596.710 \\
\hline \multicolumn{6}{|l|}{ ENERGY OUTPUT } \\
\hline Gas Turbine, MW & 87.501 & 98.882 & 89.139 & 96.908 & 103.182 \\
\hline Steam Turbine, MW & 169.369 & 151.897 & 163.932 & 156.5 .14 & 152.661 \\
\hline Auxiliaries, MW & 10.590 & 11.407 & 12.030 & 10.166 & 10.583 \\
\hline Net Plant Power, MW & 246.272 & 239.373 & 241.041 & 243.256 & 240.271 \\
\hline Thermal Efficiency, \% & 41.38 & 40.39 & 40.98 & 40.77 & 40.27 \\
\hline Net Heat Rate, (Btu/kWh) & 8,246 & 8,449 & 8,327 & 8,369 & 8,474 \\
\hline
\end{tabular}


Table 7. $110 \mathrm{MW}$ PFBC plant performance comparison.

\begin{tabular}{|c|c|c|c|c|c|}
\hline$\cdot .$. & $\begin{array}{c}\text { W/O Waste } \\
\text { Co-firing }\end{array}$ & $\underline{\mathrm{RDF}}$ & $\begin{array}{c}\text { Municipal } \\
\text { Sludge } \\
(24 \%)\end{array}$ & $\begin{array}{l}\text { Municipal } \\
\text { Sludge } \\
(6 \%)\end{array}$ & $\begin{array}{c}\text { De-Inking } \\
\text { Sludge }\end{array}$ \\
\hline \multicolumn{6}{|l|}{ ENERGY INPUT } \\
\hline Coal Feed, lb/hr & 61,581 & 56,814 & 61,634 & 61,634 & 53,457 \\
\hline Coal HHV, Btu/lb & 12,450 & 12,450 & 12,450 & 12,450 & 12,450 \\
\hline Natural Gas, lb/hr & 7,781 & 7,853 & 7,902 & 7,890 & 7,880 \\
\hline Natural Gas HHV, Btu/lb & 21,799 & 21,799 & 21,799 & 21,789 & 21,799 \\
\hline Waste Feed, $\mathrm{lb} / \mathrm{hr}$ & & 14,200 & 6,076 & 24,306 & 33,410 \\
\hline Waste HHV, Btu/lb & & 4,103 & 804 & 201 & 3,166 \\
\hline Plant Energy Input, MW & 275.345 & 274.550 & 276.844 & 276.767 & 276.434 \\
\hline \multicolumn{6}{|l|}{ ENERGY OUTPUT } \\
\hline Gas Turbine, MW & 38.107 & 43.760 & 43.491 & 44.025 & 44.735 \\
\hline Steam Turbine, MW & 77.408 & 69.320 & 71.028 & 73.048 & 68.354 \\
\hline Auxiliaries, MW & 4.774 & 5.204 & 4.608 & 7.039 & 4.806 \\
\hline Net Plant Power, MW & 110.741 & 107.875 & 109.911 & 110.035 & 108.284 \\
\hline Thermal Efficiency, \% & 40.22 & 39.29 & 39.70 & 39.76 & 39.17 \\
\hline Net Heat Rate, (Btu/kWh) & 8,484 & 8,684 & 8,594 & 8,582 & 8,711 \\
\hline
\end{tabular}

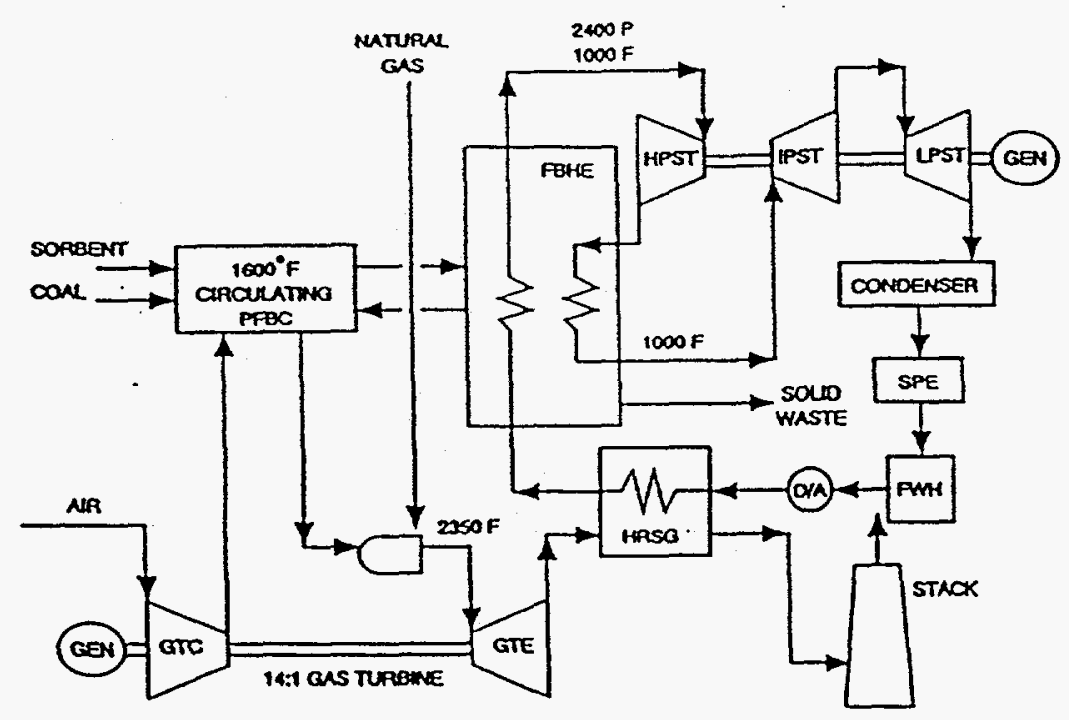

Figure 1. 1.5-Generation PFBC cycle. 
KEY WORDS

Performance Analysis

PFBC

Co-firing

Combustible Wastes

Power Plants

Environmental Issues 